\title{
PENGARUH UKURAN PERUSAHAAN DAN LEVERAGE SERTA PROFITABILITAS TERHADAP NILAI PERUSAHAAN PADA PERUSAHAAN FOOD AND BEVERAGES DI BEI
}

\author{
Ni Luh Surpa Dewantari ${ }^{1}$, Wayan Cipta ${ }^{2}$, Gede Putu Agus Jana Susila ${ }^{3}$ \\ 1,2,3Program Studi Manajemen, Jurusan Manajemen, Fakultas Ekonomi \\ Universitas Pendidikan Ganesha, Singaraja. \\ e-mail: dewantarisurpa@gmail.com, wayan.cipta@undiksha.ac.id, janos_undiksha@yahoo.com
}

\begin{abstract}
Abstrak
Penelitian ini bertujuan untuk mengetahui pengaruh secara simultan dan parsial dari ukuran perusahaan, leverage, dan profitabilitas terhadap nilai perusahaan. Desain penelitian yang digunakan adalah kuantitatif kausal dan sumber data yang digunakan yaitu data sekunder. Subjek penelitian ini adalah Perusahaan Manufaktur Sub Sektor Food and beverages yang terdaftar di Bursa Efek Indonesia dan objek dalam penelitian ini yaitu ukuran perusahaan, leverage, profitabiltas dan nilai perusahaan. Teknik pengambilan sampel yang digunakan yaitu purposive sampling dengan jumlah sampel sebanyak 11 perusahaan. Data dikumpulkan dengan pencatatan dokumen dan dianalisis dengan analisis regresi berganda. Penelitian ini menunjukkan bahwa (1) ukuran perusahaan, leverage, dan profitabilitas berpengaruh signifikan terhadap nilai perusahaan, (2) ukuran perusahaan berpengaruh positif signifikan terhadap nilai perusahaan, (3) leverage berpengaruh negatif tidak signifikan terhadap nilai perusahaan, (4) profitabilitas berpengaruh positif signfikan terhadap nilai
\end{abstract}

Kata kunci: leverage, nilai perusahaan, profitabilitas, ukuran perusahaan.

\begin{abstract}
This study aimed to determine the effect simultaneously and partialy on firm size, leverage, and profitability on the firm value. The research design was used quantitative causal and the source of the data namely secondary data. The subject of this research is Food and beverages Sub Sector Manufacturing Companies listed on the Indonesia Stock Exchange and the object of this study was firm size, leverage, profitability and firm value. The sampling technique used was purposive sampling as many as 11 companies. Data was collected by document recording and analyzed by multiple linear regression. The results showed that (1) firm size, leverage, and profitability had significant effect on the firm value, (2) firm size had positive and signifcant effect on the firm value, (3) leverage had a negative and no significant on the firm value, (4) profitability had positive and significant on the firm value.
\end{abstract}

Keywords: leverage, firm value, profitability, firm size. 


\section{Pendahuluan}

Perekonomian global saat ini secara tidak langsung berimbas bagi perekonomian di Indonesia. Keadaan politik dalam negeri juga mempengaruhi perekonomian di Indonesia. Perekonomian saat ini telah menciptakan suatu persaingan ketat antar perusahaan dalam negeri. Persaingan membuat setiap perusahaan semakin meningkatkan kinerja agar tujuannya dapat tetap tercapai. Tujuan utama perusahaan yang berorientasi pada laba salah satunya dapat meningkatkan nilai perusahaan serta mensejahterakan pemilik perusahaan atau pemegang saham. Menurut Brigham dan Houston (2001) nilai perusahaan adalah nilai yang diberikan oleh pelaku pasar saham terhadap kinerja perusahaann. Nilai perusahaan akan meningkat apabila harga saham meningkat yang ditandai dengan tingkat pengembalian investasi yang tinggi kepada pemegang saham (Suharli, 2006).

Dalam upaya mewujudkan tujuan perusahaan, perusahaan harus mencukupi kebutuhan dananya agar dapat memaksimalkan kinerjanya. Kinerja yang baik dapat meningkatkan nilai perusahaan serta harga saham perusahaan, hal ini akan mencerminkan kemakmuran para pemegang saham perusahaan. Suatu perusahaan sering mengalami kekurangan modal yang berakibat pada kinerja perusahaan barang atau jasa yang dihasilkan kurang maksimal dan perusahaan tidak mampu bersaing di pasar serta mengalami perkembangan yang lambat. Perusahaan memperoleh sumber dana dari dalam perusahaan berupa modal sendiri, penyusutan dan laba ditahan, sedangkan sumber dana dari luar perusahaan berupa hutang dan penerbitan saham.

Nilai perusahaan pada dasarnya dapat diukur melalui beberapa aspek, salah satunya adalah dengan harga pasar saham perusahaan karena harga pasar saham perusahaan mencerminkan penilaian investor secara keseluruhan atas setiap ekuitas yang dimiliki. Harga pasar saham menunjukkan penilaian sentral dari seluruh pelaku pasar saham bertindak sebagai barometer kinerja manajemen perusahaan. Persepsi investor pada tingkat keberhasilan perusahaan dicerminkan melalui nilai perusahaan. Peningkatan nilai perusahaan karena tingginya harga saham akan membuat pasar percaya pada kinerja perusahaan dan prospeknya dimasa yang akan datang. Meningkatkan laba perusahaan dan memaksimumkan nilai perusahaan merupakan tujuan perusahaan yang saling berkaitan untuk meningkatkan kesejahteraan para pemegang saham, sehingga tujuan tersebut akan menjadi kriteria penting untuk menjaga kelangsungan hidup perusahaan. Nilai perusahaan merupakan persepsi investor terhadap tingkat keberhasilan perusahaan yang sering dikaitkan dengan harga saham (Sujoko dan Soebiantoro, 2007). Ada beberapa alat ukur dari nilai perusahaan, salah satunya yaitu Price Earning Ratio (PER). PER adalah salah satu ukuran paling dasar dalam analisis saham secara fundamental. PER adalah perbandingan antara harga pasar saham dengan laba bersih per saham, dimana harga saham sebuah emiten dibandingkan dengan laba bersih yang dihasilkan oleh emiten tersebut dalam setahun. Menurut Setia (2008) menyatakan bahwa jika ukuran perusahaan dan profitabilitas meningkat serta leverage menurun maka akan meningkatkan nilai perusahaan.

Ukuran perusahaan adalah suatu skala dimana dapat diklasifikasikan besar kecilnya perusahaan dengan berbagai cara antara lain total aktiva, nilai pasar saham, log size dan lainlain ukuran perusahaan dianggap mampu mempengaruhi nilai perusahaan (Bendriani, 2011). Semakin besar ukuran atau skala perusahaan maka akan semakin mudah pula perusahaan memperoleh sumber pendanaan baik yang bersifat internal maupun eksternal. Ukuran perusahaan merupakan cerminan total dari aset yang dimiliki suatu perusahaan. Perusahaan sendiri dikategorikan menjadi dua jenis, yaitu perusahaan berskala kecil dan perusahaan berskala besar. Perusahaan yang berskala besar cenderung akan menarik minat investor karena akan berimbas dengan nilai perusahaan, sehingga dapat dikatakan bahwa besar 
kecilnya ukuran suatu perusahaan secara langsung berpengaruh terhadap nilai dari perusahaan tersebut. Ukuran perusahaan diukur dengan total asset perusahaan yang diperoleh laporan keuangan perusahaan. Ukuran perusahaan dapat dilihat oleh investor melalui suatu indikator yang digambarkan tingkat rasio untuk melakukan suatu investasi atau besaran investasi. Ukuran perusahaan dianggap mampu mempengaruhi nilai perusahaan. Ukuran perusahaan yang besar mencerminkan bahwa perusahaan tersebut sedang mengalami perkembangan dan pertumbuhan yang baik sehingga meningkatkan nilai dari suatu perusahaan. Nilai perusahaan yang meningkat dapat ditandai dengan total aktiva perusahaan yang mengalami kenaikan dan lebih besar dibandingkan dengan jumlah hutang perusahaan. Semakin besar aset suatu perusahaan maka akan semakin besar pula modal yang ditanam, semakin besar total penjualan suatu perusahaan maka akan semakin banyak juga perputaran uang dan semakin besar kapitalisasi pasar maka semakin besar pula perusahaan dikenal masyarakat (Sudarmadji dan Sularto, 2007).

Semakin besar ukuran perusahaan maka ada kecenderungan lebih banyak investor yang menaruh perhatian pada perusahaan tersebut, sehingga akan meningkatkan nilai perusahaan dimata investor, hal ini disebabkan karena perusahaan yang besar cenderung memiliki kondisi yang lebih stabil (Riyanto, 2001: 313). Penelitian dari Rudangga dan Sudiarta (2016) menemukan bahwa ukuran perusahaan berpengaruh positif dan signifikan terhadap nilai perusahaan.

Hasil penelitian ini menunjukkan bahwa ukuran perusahaan yang besar menjamin nilai perusahaannya tinggi, karena perusahaan besar mungkin berani melakukan investasi baru terkait dengan ekspansi, sebelum kewajiban-kewajibannya (hutang sudah terlunasi). Hasil penelitian ini sejalan dengan hasil penelitian dari Novari dan Lestari (2016) yang menyatakan bahwa ukuran perusahaan berpengaruh positif dan signifikan terhadap nilai perusahaan. Penelitian yang dilakukan oleh Astriani (2014) memiliki hasil yang bertentangan, bahwa ukuran perusahaan berpengaruh negatif dan signifikan terhadap nilai perusahaan.

Leverage merupakan pemakaian utang oleh perusahaan untuk melakukan kegiatan operasional perusahaan. Hutang (leverage) yang merupakan rasio utang atau sering juga dikenal dengan nama rasio solvabilitas adalah rasio yang dapat menunjukkan kemampuan dari suatu perusahaan untuk memenuhi segala kewajiban finansial dari perusahaan tersebut seandainya perusahaan tersebut dilikuidasi (Agnes, 2004). Leverage juga sebagai salah satu alat yang banyak digunakan oleh perusahaan untuk meningkatkan modal mereka dalam rangka meningkatkan keuntungan (Singapurwoko, 2011). Hutang berasal dari bank atau pembiayaan lainnya. Perusahaan yang terlalu banyak melakukan pembiayaan dengan hutang, dianggap tidak sehat karena dapat menurunkan laba. Peningkatan dan penurunan tingkat hutang memiliki pengaruh terhadap penilaian pasar (Nor, 2012).

Kelebihan hutang yang besar akan memberikan dampak yang negatif pada nilai perusahaan (Ogolmagai, 2013). Dalam penelitian ini menggunakan indikator Debt to Equity Ratio (DER) sebagai pengukuran Leverage. DER adalah rasio perbandingan antara hutang yang dimiliki perusahaan dan modal sendiri yang digunakan sebagai pendanaan usaha. Semakin besar leverage maka risiko perusahaan tidak mampu membayar kewajibannya semakin besar, sehingga berpengaruh terhadap turunnya nilai perusahaan (Darsono, 2006: 54).

Penelitian dari Novari dan Lestari (2016) menemukan bahwa leverage berpengaruh negatif dan signifikan terhadap nilai perusahaan. Astriani (2014) menemukan bahwa leverage berpengaruh negatif dan signifikan terhadap nilai perusahaan. Tidak berpengaruhnya leverage 
terhadap nilai perusahaan disebabkan karena manajer belum memanfaatkan sumber dana eksternal secara efektif, sehingga leverage tidak mempengaruhi nilai perusahaan. Hasil penelitian ini sejalan dengan Sari (2013) yang menemukan bahwa leverage berpengaruh negatif dan signifikan terhadap nilai perusahaan. Penelitian yang dilakukan oleh Rudangga dan Sudiarta (2016) memiliki hasil yang bertentangan, bahwa leverage berpengaruh positif dan signifikan terhadap nilai perusahaan.

Profitabilitas juga dapat mempengaruhi nilai perusahaan. Besar kecilnya profitabilitas yang dihasilkan suatu perusahaan dapat mempengaruhi nilai perusahaan dengan melihat profitabilitas sebagai ukuran dan kinerja perusahaan yang ditunjukkan dari laba yang dihasilkan oleh perusahaan. Dengan melihat laba yang dihasilkan suatu perusahaan, jika perusahaan mampu membuatkan laba yang meningkat, hal itu mengindikasikan perusahaan tersebut mampu berkinerja dengan baik sehingga dapat menciptakan tanggapan yang positif dari investor dan juga meningkatkan harga saham dari perusahaan tersebut. Perusahaan yang memiliki profitabilitas yang tinggi menunjukkan bahwa perusahaan tersebut mengelola kekayaan perusahaan secara efektif dan efisien dalam memperoleh laba setiap periode (Horne dan Wachowicz, 2005: 222).

Menurut Husnan (2002: 56) profitabilitas adalah hasil bersih dari berbagai kebijaksanaan dan keputusan yang diterapkan oleh sebuah perusahaan. Nilai dari suatu perusahaan dipengaruhi oleh besar kecilnya profitabilitas yang dihasilkan oleh perusahaan tersebut, karena semakin besar profitabilitas akan membuat nilai perusahaan semakin tinggi dan membuat investor berani berinvestasi di perusahaan tersebut. Dalam penelitian ini menggunakan Return On Equity (ROE) sebagai indikator pengukuran profitabilitas. Menurut Prihadi (2014: 261) ROE adalah rasio laba atas ekuitas bagi pemilik modal, rasio ini lebih penting dari rasio laba bersih terhadap penjualan, yaitu untuk mengetahui sampai seberapa jauh hasil yang diperoleh dari penanaman modalnya. Rasio ini menunjukkan hasil perbandingan laba bersih dengan ekuitas. Rasio ini digunakan untuk mengukur sampai seberapa besar efektivitas manajemen dalam mengelola asset dan equity yang dimiliki perusahaan untuk menghasilkan laba. Tinggi rendahnya rasio seringkali merefleksikan kemampulabaan dan efektivitas penggunaan asset. Semakin besar tingkat pengembalian atas modal sendiri maka akan mendorong peningkatan harga saham sehingga diharapkan nilai perusahaan akan meningkat (Tambunan, 2007: 146). Penelitian dari Denziana dan Monica (2016) menemukan bahwa profitabilitas berpengaruh positif dan signifikan terhadap nilai perusahaan. Rasio yang meningkat menunjukkan bahwa kinerja manajemen meningkat dalam mengelola sumber dana pembiayaan operasional secara efektif untuk menghasilkan laba bersih (profitabilitas meningkat). Hal ini sejalan dengan penelitian Prasetyorini (2013) menemukan bahwa profitabilitas berpengaruh positif terhadap nilai perusahaan. Namun hal sebaliknya ditemukan dalam penelitian Herawati (2012) bahwa profitabilitas secara signifikan berpengaruh negatif terhadap nilai perusahaan. Perusahaan manufaktur khususnya sub sektor food and beverages merupakan perusahaan yang memiliki prospek yang baik bagi investor untuk menanamkan investasi pada perusahaan tersebut karena perusahaan manufaktur khususnya pada sub sektor food and beverages memiliki tuntutan untuk terus berkompetitif dan terus berinovasi dalam menciptakan suatu produk yang berkualitas serta mampu bersaing secara global. Menarik minat investor tentunya menjadi hal yang cukup sulit bagi perusahaan. Jadi, perusahaan harus mampu meningkatkan profitabilitas agar dapat meningkatkan nilai perusahaan di mata investor.

Perkembangan mengenai ukuran perusahaan, leverage, profitabilitas dan nilai perusahaan pada perusahaan food and beverages yang terdaftar di Bursa Efek Indonesia selama periode 2015-2018 menunjukkan bahwa PT Wilmar Cahaya Indonesia mengalami 
penurunan ukuran perusahaan tetapi nilai perusahaan meningkat sedangkan pada PT Siantar Top, PT Tri Banyan Tirta, dan PT Sekar Bumi mengalami peningkatan ukuran tetapi nilai perusahaan menurun. Hal ini tidak sesuai dengan teori Riyanto (2001: 313) yang menyatakan bahwa "semakin besar ukuran perusahaan maka ada kecenderungan lebih banyak investor yang menaruh perhatian pada perusahaan tersebut, sehingga akan meningkatkan nilai perusahaan dimata investor, hal ini disebabkan karena perusahaan yang besar cenderung memiliki kondisi yang lebih stabil". PT Wilmar Cahaya Indonesia mengalami penurunan leverage tetapi mengalami penurunan nilai perusahaan. PT Siantar Top dan PT Tri Banyan Tirta mengalami peningkatan leverage sedangkan nilai perusahaan mengalami peningkatan. Pada PT Sekar Bumi mengalami penurunan leverage pada tahun dan nilai perusahaan mengalami penurunan sebesar. Hal ini tidak sejalan dengan teori Darsono (2006: 54) "semakin besar leverage maka risiko perusahaan tidak mampu membayar kewajibannya semakin besar, sehingga berpengaruh terhadap turunnya nilai perusahaan. Pada PT Wilmar Cahaya Indonesia, PT Siantar Top, PT Sekar Bumi mengalami penurunan profitabilitas tetapi nilai perusahaan mengalami peningkatan sedangkan pada PT Tri Banyan Tirta mengalami peningkatan tetapi nilai perusahaan menurun. Hal ini tidak sejalan dengan teori Tambunan (2007: 146), Semakin besar tingkat pengembalian atas modal sendiri maka akan mendorong peningkatan harga saham sehingga diharapkan nilai perusahaan akan meningkat.

Penelitian yang membahas faktor-faktor yang mempengaruhi nilai perusahaan yang telah banyak dilakukan. Penelitian-penelitian sebelumnya telah menemukan bukti-bukti empiris bahwa nilai perusahaan dipengaruhi oleh beberapa faktor dengan hasil penelitian yang berbeda-beda. Penelitian mengenai ukuran perusahaan pernah dilakukan oleh Rudangga dan Sudiarta (2016) yang menyatakan bahwa ukuran perusahaan berpengaruh positif dan signifikan terhadap nilai perusahaan. Berbeda dengan penelitian yang dilakukan Astriani (2014) menunjukkan bahwa ukuran perusahaan berpengaruh negatif dan signifikan terhadap nilai perusahaan. Penelitian mengenai leverage pernah dilakukan Novari dan Lestari (2016) menemukan bahwa leverage berpengaruh negatif dan signifikan terhadap nilai perusahaan. Berbeda dengan penelitian yang dilakukan Rudangga dan Sudiarta (2016) menunjukkan bahwa leverage berpengaruh positif dan signifikan terhadap nilai perusahaan. Penelitian mengenai profitabilitas pernah dilakukan Denziana dan Monica (2016) menemukan bahwa profitabilitas berpengaruh positif dan signifikan terhadap nilai perusahaan. Berbeda dengan penelitian yang dilakukan Herawati (2012) bahwa profitabilitas secara signifikan berpengaruh negatif terhadap nilai perusahaan.

Berdasarkan latarbelakang penelitian dan rumusan masalah yang ada, maka tujuan penelitian ini adalah untuk menguji hal-hal sebagai berikut: (1) pengaruh ukuran perusahaan, leverage dan profitabilitas secara simultan terhadap nilai perusahaan pada perusahaan food and beverages yang terdaftar di Bursa Efek Indonesia. (2) pengaruh ukuran perusahaan, leverage dan profitabilitas secara parsial terhadap nilai perusahaan pada perusahaan food and beverages yang terdaftar di Bursa Efek Indonesia.

\section{Kajian Pustaka dan Perumusan Hipotesis Hubungan antara Ukuran Perusahaan, Leverage dan Profitabilitas terhadap Nilai Perusahaan}

Nilai perusahaan pada dasarnya dapat dilihat dari ukuran perusahaannya yang memiliki aset yang besar dan penggunaan hutang (leverage) yang sedikit dengan menghasilkan profitabilitas yang tinggi. Hal ini didukung oleh Setia (2008) menyatakan bahwa faktor-faktor yang mempengaruhi nilai perusahaan, yaitu: keputusan pendanaan, kebijakan dividen, 
keputusan investasi, struktur modal, profitabilitas, leverage, pertumbuhan perusahaan dan ukuran perusahaan

H1: Ada pengaruh ukuran perusahaan, leverage, dan profitabilitas terhadap nilai perusahaan

\section{Hubungan Ukuran Perusahaan terhadap Nilai Perusahaan}

Ukuran perusahaan yang semakin tinggi akan berkaitan erat dengan keputusan pendanaan yang akan diterapkan oleh perusahaan guna mengoptimalkan nilai perusahaan. Umumnya perusahaan yang berukuran besar cenderung lebih mudah untuk mendapat kepercayaan dari pihak kreditur untuk mendapatkan sumber pendanaan sehingga dapat meningkatkan nilai perusahaan (Pramana dan Mustanda, 2016). Ukuran perusahaan yang berskala besar lebih mudah meningkatkan nilai perusahaan dan menarik minat investor untuk berinvestasi serta lebih mudah mendapatkan kepercayaan dari pihak kreditur. Semakin besar ukuran perusahaan maka ada kecenderungan lebih banyak investor yang menaruh perhatian pada perusahaan tersebut, sehingga akan meningkatkan nilai perusahaan dimata investor, hal ini disebabkan karena perusahaan yang besar cenderung memiliki kondisi yang lebih stabil (Riyanto, 2001: 313).

H2: Ada pengaruh ukuran perusahaan terhadap nilai perusahaan

\section{Hubungan Leverage terhadap Nilai Perusahaan}

Pengelolaan leverage sangatlah penting, sebab keputusan dalam penggunaan hutang yang tinggi dapat meningkatkan nilai perusahaan yang dikarenakan adanya pengurangan atas pajak penghasilan. Leverage juga bisa sebagai salah satu alat yang banyak digunakan oleh perusahaan untuk meningkatkan modal mereka dalam rangka meningkatkan keuntungan Penggunaan hutang yang terlalu banyak tidak baik karena dikhawatirkan bahwa akan terjadi penurunan laba yang diperoleh perusahaan. Artinya, nilai leverage yang semakin tinggi akan menggambarkan investasi yang dilakukan berisiko besar, sedangkan leverage yang kecil akan menunjukkan investasi yang dilakukan berisiko kecil. Darsono (2006: 54) yang menyatakan bahwa "Semakin besar leverage maka risiko perusahaan tidak mampu membayar kewajibannya semakin besar, sehingga berpengaruh terhadap turunnya nilai perusahaan".

H3: Ada pengaruh leverage terhadap nilai perusahaan

\section{Hubungan Profitabilitas terhadap Nilai Perusahaan}

Nilai dari suatu perusahaan dipengaruhi oleh besar kecilnya profitabilitas yang dihasilkan oleh perusahaan tersebut, karena semakin besarnya profitabilitas akan membuat nilai perusahaan semakin tinggi dan membuat investor berani berinvestasi di perusahaan tersebut. Home dan Wachowicz (2005: 222) menyatakan, apabila profitabilitas suatu perusahaan tinggi, maka menunjukkan perusahaan bekerja secara efisien dan efektif dalam mengelola kekayaan perusahaan dalam memperoleh laba setiap periodenya. Tambunan (2007: 146) yang menyatakan bahwa "Semakin besar tingkat pengembalian atas modal sendiri maka akan mendorong peningkatan harga saham, sehingga diharapkan nilai perusahaan akan meningkat".

H4: Ada pengaruh profitabilitas terhadap nilai perusahaan

\section{Metode}

Rancangan penelitian yang digunakan dalam penelitian ini adalah penelitian kuantitatif kausal yaitu penelitian yang menggambarkan suatu generalisasi atau menjelaskan hubungan 
sebab akibat dari dua atau beberapa variabel. Penelitian ini digunakan untuk menguji pengaruh ukuran perusahaan, leverage, profitabilitas dan nilai perusahaan pada perusahaan food and beveragesyang terdaftar di Bursa Efek Indonesia. Subjek dalam penelitian ini adalah perusahaan food and beverages yang terdaftar di Bursa Efek Indonesia pada tahun 2015 2018. Sedangkan objek yang digunakan dalam penelitian ini adalah ukuran perusahaan, leverage, profitabilitas dan nilai perusahaaan.

Metode pengumpulan data yang digunakan dalam penelitian ini adalah pencatatan dokumen yaitu pengumpulan data dengan mengutip catatan atau dokumen pada ikhtisar keuangan pada perusahaan food and beverages yang terdaftar di Bursa Efek Indonesia.

Penelitian ini menggunakan metode analisis regresi linier berganda dengan menggunakan alat bantu program komputer Statistical Package for Sosial Science (SPSS) versi 22.0 for Windows untuk menjawab rumusan masalah dan menguji hipotesis yang dilakukan. Sebelum melakukan analisis regresi linier berganda, terlebih dahulu harus memenuhi uji asumsi klasik. Uji asumsi klasik meliputi: (1) Uji Normalitas, (2) Uji Autokorelasi, (3) Uji Multikolonieritas, dan (4) Uji Heterokedastisitas.

\section{Hasil dan Pembahasan}

Penelitian ini menggunakan model analisis regresi linier berganda dengan bantuan program SPSS 22.0 for Windows. Berdasarkan hasil pengujian berupa Ringkasan Hasil Output Perhitungan SPSS 22.0 for Windows terhadap pengaruh ukuran perusahaan, leverage, profitabilitas terhadap nilai perusahaaan.

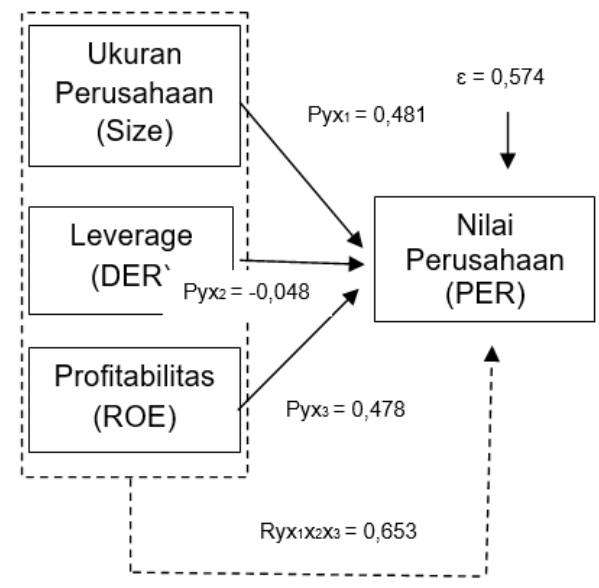

Berdasarkan hasil uji regresi linier berganda diperoleh nilai konstanta $(\alpha)$ sebesar-27,200, nilai koefisien regresi ukuran perusahaan $(\beta 1)$ sebesar 0,420 , nilai koefisien regresi leverage $(\beta 2)$ sebesar $-0,046$, dan nilai koefisien regresi profitabilitas $(\beta 3)$ sebesar 0,520 . Sehingga persamaan regresi diformulasikan sebagai berikut.

$$
Y=-27,200+0,420 \times 1-0,046 \times 2+0,520 X 3+0,574
$$

Interpretasi dari hasil analisis regresi linier berganda sebagai berikut.

(1)Konstanta sebesar $-27,200$ artinya bahwa apabila, ukuran perusahaan $(\beta 1)$ danleverage $(\beta 2)$, serta profitabilitas ( $\beta 3)$ nilainya sama dengan nol, maka Nilai Perusahaan (Y) sebesar 27,200 . (2) Nilai koefisien ukuran perusahaan $(\beta 1)$ sebesar 0,420 berpengaruh positif terhadap nilai perusahaan $(\mathrm{Y})$. Hal ini mengandung arti bahwa setiap kenaikan ukuran perusahaan ( $\beta 1$ ) satu satuan maka variabel nilai perusahaan $(Y)$ naik sebesar 0,420 , sehingga nilai dari nilai 
perusahaan menjadi $-26,78$ dengan asumsi bahwa variabel bebas yang lainnya tetap. (3) Nilai koefisien leverage $(\beta 2)$ sebesar $-0,046$ berpengaruh negatif terhadap nilai perusahaan $(Y)$. Hal ini mengandung arti bahwa setiap kenaikan leverage $(\beta 2)$ satu satuan maka variabel ROA $(Y)$ turun sebesar $-0,046$ sehingga nilai dari nilai perusahaan menjadi $-27,246$ dengan asumsi bahwa variabel bebas yang lainnya tetap. (4) Nilai koefisien profitabilitas (B3) sebesar 0,520 berpengaruh positif terhadap nilai perusahaan $(Y)$. Hal ini mengandung arti bahwa setiap kenaikan profitabilitas $(\beta 3)$ satu satuan maka variabel $R O A(Y)$ naik sebesar 0,520 sehingga nilai dari nilai perusahaan 26,68 menjadi dengan asumsi bahwa variabel bebas yang lainnya tetap. (5) Nilai error sebesar 0,574 dengan asumsi bahwa masih ada variabel lain yang mempengaruhi nilai perusahaan selain ukuran perusahaan, leverage dan profitabilitas.

\section{Koefisien Determinasi}

Koefisien Determinasi (R2) digunakan untuk mengukur seberapa besar sumbangan pengaruh variabel bebas terhadap variabel terikat. Nilai R2 sebesar 0,426 (42,6\%). Hasil ini menunjukkan bahwa Nilai Perusahaan dipengaruhi oleh Ukuran Perusahaan, Leverage, dan Profitabilitas sebesar 0,426 (42,6\%), sedangkan 0,574 (57,4\%) dipengaruhi oleh variabel lain.

\section{Pembahasan}

Berdasarkan hasil dari penelitian yang telah dilakukan dapat dijelaskan sebagai berikut: (1) pengaruh ukuran perusahaan, leverage dan profitabilitas terhadap nilai perusahaan menunjukkan bahwa terdapat pengaruh secara simultan atau signifikan secara bersama-sama. Hasil ini menunjukkan bahwa ukuran perusahaan, leverage dan profitabilitas berpengaruh terhadap nilai perusahaan pada perusahaan food and beverages. Hasil dari penelitian ini didukung penelitian yang dilakukan Rahayu dan Sari (2018) yang menyatakan bahwa leverage, ukuran perusahaan dan profitabilitas bersama-sama berpengaruh simultan terhadap nilai perusahaan. (2) ukuran perusahaan berpengaruh positif dan signifikan terhadap nilai perusahaan pada perusahaan food and beverages. Hasil dari penelitian ini didukung penelitian yang dilakukan Rudangga dan Sudiarta (2016) yang menyatakan bahwa ukuran perusahaan berpengaruh positif dan signifikan terhadap nilai perusahaan. (3) Leverage berpengaruh negatif terhadap nilai perusahaan di perusahaan food and beverages. Hasil dari penelitian ini didukung penelitian yang dilakukan Novari dan Lestari (2016) menemukan bahwa leverage berpengaruh negatif dan signifikan terhadap nilai perusahaan.(4) Profitabilitas berpengaruh positif dan signifikan terhadap nilai perusahaan pada perusahaan food and beverages. Hasil dari penelitian ini didukung penelitian yang dilakukan Denziana dan Monica (2016) menemukan bahwa profitabilitas berpengaruh positif dan signifikan terhadap nilai perusahaan, yang berarti adanya peningkatan profitabilitas maka nilai perusahaan akan meningkat.

\section{Simpulan dan Saran Simpulan}

Berdasarkan hasil penelitian yang telah dilakukan pada perusahaan sub sektor food and beverages yang terdaftar di Bursa Efek Indonesia periode 2015-2018 yang telah dipaparkan sebelumnya, maka dapat disimpulkan sebagai berikut: (1) Ukuran perusahaan, leverage dan profitabilitas berpengaruh signifikan secara simultan terhadap nilai perusahaan pada perusahaan sub sektor food and beverages. Artinya faktor yang mempengaruhi nilai perusahaan pada perusahaan sub sektor food and beverages yakni dapat dilihat dengan ukuran perusahaan, leverage dan profitabilitas sebagai variabel yang menentukan besar kecilnya sebuah perusahaan dalam pengelolaan aset perusahaan yang baik agar meningkatkan laba yang diperoleh perusahaan untuk meningkatkan nilai dari suatu perusahaan. (2) Ukuran perusahaan berpengaruh secara positif dan signifikan terhadap nilai 
perusahaan pada perusahaan sub sektor food and beverages. Artinya apabila variabel ukuran perusahaan meningkat maka akan meningkatkan nilai perusahaan pada perusahaan sub sektor food and beverages. Hal ini sejalan dengan pendapat dari Riyanto (2001: 313) Semakin besar ukuran perusahaan maka ada kecenderungan lebih banyak investor yang menaruh perhatian pada perusahaan tersebut, sehingga akan meningkatkan nilai perusahaan dimata investor, hal ini disebabkan karena perusahaan yang besar cenderung memiliki kondisi yang lebih stabil. (3) Leverage berpengaruh negatif dan tidak signifikan terhadap nilai perusahaan pada perusahaan sub sektor food and beverages. Artinya variabel leverage tidak memiliki pengaruh terhadap nilai perusahaan. karena dalam hal ini perusahaan menggunakan lebih banyak modal sendiri dan laba ditahan untuk membiayai kegiatan operasionalnya sehingga dalam penggunaan proporsi hutang relatif rendah. (4) Profitabilitas berpengaruh positif dan signifikan terhadap nilai perusahaan pada perusahaan sub sektor food and beverages. Artinya apabila variabel profitabilitas meningkat dengan pengelolaan profitabilitas yang baik maka akan meningkatkan nilai perusahaan.

\section{Saran}

Berdasarkan hasil penelitian dan pembahasan serta kesimpulan yang telah dipaparkan sebelumnya, maka dapat diajukan saran sebagai berikut.

(1) Bagi perusahaan food and beverages, diharapkan agar lebih meningkatkan kinerja perusahan dan memperhatikan variabel ukuran perusahaan, leverage, dan profitabilitas yang dianggap penting dalam perusahaan yang dapat mempengaruhi harga saham dan meningkatkan nilai perusahaan. Dengan ukuran perusahaan dan profitabilitas yang tinggi diikuti dengan pengelolaan keuangan yang baik akan meningkatkan nilai perusahaan. Untuk leverage perusahaan disarankan untuk mengurangi penggunaan hutang yang besar dari pihak ketiga untuk operasional perusahaan karena penggunaan hutang yang besar tentunya akan menambah beban perusahaan dan penggunaan hutang yang rendah akan menguntungkan perusahaan sehingga bisa meningkatkan nilai perusahaan. (2) Bagi peneliti selanjutnya, diharapkan untuk dapat mengembangkan penelitian ini dengan menggunakan subjek penelitian yang lebih luas. Peneliti juga diharapkan melakukan pengujian terhadap variabel lain yang mempengaruhi nilai perusahaan seperti pertumbuhan perusahaan, kebijakan dividen, keputusan investasi maupun yang lainnya. Sehingga, dengan dilakukan penelitian menggunakan variabel lain akan diketahui seberapa besar pengaruh variabel lain terhadap nilai perusahaan.

\section{Daftar Pustaka}

Agnes, Sawir. 2004. Analisis Kinerja Keuangan dan Perencanaan Keuangan Perusahaan. Jakarta: PT Gramedia Pustaka Utama

Bendriani, Mala. 2011. Pengaruh Struktur Kepemilikan Dan Kesempatan Investasi (IOS) Terhadap Nilai Perusahaan. Skripsi. UNP.

Brigham, Eugene F dan Joel F. Houston. 2001. Manajemen Keuangan (Buku 1). Jakarta: Erlangga.

Brigham, Eugene F dan Joel F. Houston. 2001. Dasar-Dasar Manajemen Keuangan. Edisi Kesepuluh Buku Kedua. Jakarta: Salemba Empat.

Darsono. 2006. Manajemen Keuangan Pendekatan Praktis. Jakarta: Diadit Media.

Darsono, Purwanti Arif. 2008. Penganggaran Perusahaan. Jakarta: Mitra Wacana. 
Dewi, Ayu Sri Mahatma dan Wirajaya, Ary. 2013. Pengaruh Struktur Modal, Profitabilitas Dan Ukuran Perusahaan Pada Nilai Perusahaan. E-Jurnal Akuntansi Universitas Udayana 4.2 .

Husnan, Suad. 2009. Dasar-Dasar Teori Portofolio dan Analisis Sekuritas. Yogyakarta: AMP YKPN.

Kasmir. 2009. Pengantar Manajemen Keuangan. Jakarta: Kencana.

Nurmayasari, Andi. 2012. Analisis Pengaruh Profitabilitas, Ukuran Perusahaan, Leverage, dan Kebijakan Dividen Terhadap Nilai Perusahaan(Studi Kasus Pada Perusahaan Manufaktur Di Bursa Efek Indonesia Tahun 2007-2010). Skripsi. Fakultas Ekonomi Universitas Islam Indonesia.

Ogolmagai, Natalia. 2013. Leverage Pengaruhnya Terhadap Nilai Perusahaan Pada Industri Manufaktur Yang Go Public Di Indonesia. Jurnal EMBA 8I.1(3) hal: 81-89.

Prihadi, Toto. 2014. Memahami Laporan Keuangan Sesuai IFRS Dan PSAK. Jakarta: PPM.

Rahayu, Maryati dan Sari, Bida. 2018. Faktor-Faktor Yang Mempengaruhi Nilai Perusahaan. IKRATH-HUMANIORA, Vol.2.No.2.

Riyanto, Bambang. 2001. Dasar-dasar Pembelanjaan Perusahaan. Edisi Keempat. Yogyakarta: Yayasan Penerbit Gajah Mada.

Rudangga, I Gusti Ngurah Gede dan Sudiarta, Gede Merta. 2016. Pengaruh Ukuran Perusahaan, Leverage, Dan Profitabilitas Terhadap Nilai Perusahaan. E-Jurnal Manajemen UNUD, Vol.5.No.7.

Setia, Lukas. 2008. Teori Dan Praktik Manajemen Keuangan. Yogyakarta: ANDI.

Singapurwoko, Arif dan Muhammad Shalahuddin Mustofa El-Wahid. 2011. The Impact of Financial Leverage to Probability Study of Non-Financial Companies Listed in Indonesia Stock Exchange. Europian Jurnal of Economics. Finance And Administrative Science. $\mathrm{H}: 137-148$.

Sudarmadji, Ardi Murdoko dan Lana Sularto. 2007. Pengaruh Ukuran Perusahaan, Profitabilitas, Leverage, dan Tipe Kepemilikan Perusahaan Terhadap Luas Voluntary Disclosure Laporan Keuangan Tahunan, Proceeding PESAT, Volume 2. Universitas Gunadarma Jakarta.

Suharli, Michaell. 2006. Studi Empiris Terhadap Faktor Yang Mempengaruhi Nilai Perusahaan Go Publik Di Indonesia. Jurnal Maksi.6(1).

Sujoko dan Soebiantoro. 2007. Pengaruh Kepemilikan Saham, Leverage, Faktor Intern dan Faktor Ekstern Terhadap Nilai Perusahaan (Studi Emperik Pada Perusahaan Manufaktur Di Bursa Efek Jakarta). Dalam Jurnal Manajemen dan Kewirausahaan. G(1): h: 41-48.

Suliyanto. 2011. Ekonometrika Terapan: Teori dan Aplikasi Dengan SPSS. Edisi I. Yogyakarta: CV. ANDI OFFSET.

Tambunan, Andy Porman. 2007. Menilai Harga Wajar Saham. Editor Edhi S. Widjojo. Jakarta: Gramedia. 